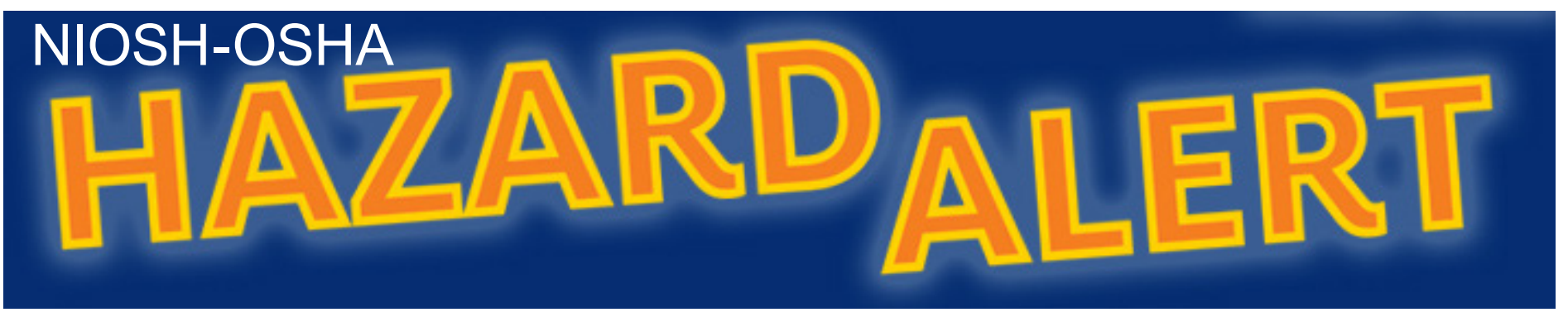

\title{
Health and Safety Risks for Workers Involved in Manual Tank Gauging and Sampling at Oil and Gas Extraction Sites
}

\begin{abstract}
The National Institute for Occupational Safety and Health (NIOSH) and the Occupational Safety and Health Administration (OSHA) have identified health and safety risks to workers who manually gauge or sample fluids on production and flowback tanks from exposure to hydrocarbon gases and vapors, exposure to oxygen-deficient atmospheres, and the potential for fires and explosions.
\end{abstract}

\section{Introduction}

Workers at oil and gas extraction sites could be exposed to hydrocarbon gases and vapors, oxygen-deficient atmospheres, and fires and explosions when they open tank hatches to manually gauge or collect fluid samples on production, flowback, or other tanks (e.g., drip pots) that contain process fluids. Opening tank hatches, often referred to as "thief hatches," can result in the release of high concentrations of hydrocarbon gases and vapors. These exposures can have immediate health effects, including loss of consciousness and death.

Recent NIOSH and OSHA research showed that workers could be exposed to hydrocarbon gases and vapors when they work on or near production and flowback tanks. This means workers can face significant health and safety risks when they manually gauge or sample tanks [Esswein et al. 2014; Jordan 2015]. These risks are in addition to the risk of exposure to hydrogen sulfide $\left(\mathrm{H}_{2} \mathrm{~S}\right)$, a well-recognized chemical exposure hazard for those who work in the oil and gas extraction and production industry [OSHA].

NIOSH and OSHA also identified nine worker fatalities that occurred while workers manually gauged or sampled production tanks from 2010-2014 [NIOSH 2015]. Exposures to hydrocarbon gases and vapors and/or oxygen-deficient atmospheres are believed to be primary or contributory factors to the workers' deaths [Harrison et al. 2016].

Working on or near oil and gas production tanks is of particular concern because these tanks may contain concentrated hydrocarbon gases and vapors that are under pressure. When the thief hatch is opened, the release of these pressurized gases and vapors can expose workers. Second, the gases and vapors can displace

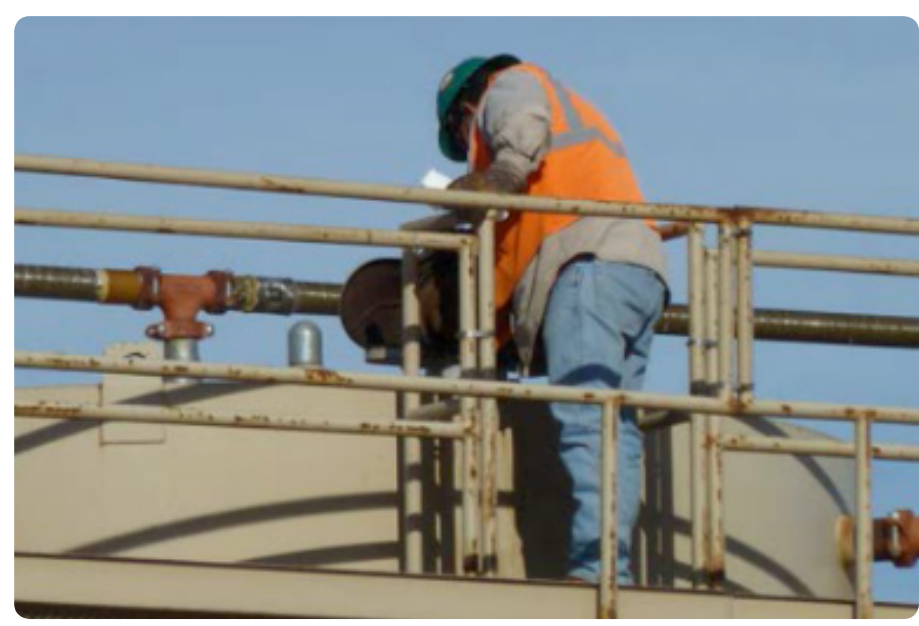

A worker collecting a sample from the open hatch of a production tank. Image: J.D. Danni, OSHA.

oxygen, creating an oxygen-deficient environment. Third, the hydrocarbon gas and vapor concentrations can exceed $10 \%$ of the lower explosive limit (LEL), creating a chance for fires and explosions. Exposure to hazardous atmospheres and fire/explosion risks will vary depending on tank contents and operating conditions, the presence of ignition sources, and other factors (Box 1, page 3).

\section{What's in this Alert?}

This Hazard Alert describes the safety and health hazards when workers manually gauge or sample fluids from production, flowback, or other tanks. It recommends ways to protect workers by eliminating or reducing exposures to hazardous atmospheres, and actions employers should take to ensure that workers are properly aware of the hazards and protected from exposure to hydrocarbon gases and vapors. This alert is a supplement to the OSHA Alliance Tank Hazard Alert released in 2015 [National STEPS Network 2015]. 


\section{Hydrocarbon Gas and Vapor Release from Production and Flowback Tanks}

Petroleum hydrocarbons can exist as liquids, gases, and vapors. Production liquids (e.g., crude oil and condensate) at oil and gas extraction sites can release dissolved hydrocarbon gases such as methane, ethane, propane, and butane. Production liquids also evaporate to produce vapors such as pentane, hexane, benzene, and xylene. Hydrocarbon gases and vapors are often referred to as volatile organic compounds, or "VOCs." Hydrocarbon gases contained in crude oil are readily released into the air at ambient temperature and pressure.

When a thief hatch is opened, substantial amounts of hydrocarbon gas and vapor (>100,000 parts per million) can be released [Jordan 2015], and in some cases this release can continue even after the initial headspace pressure is released. Furthermore, the composition of hydrocarbons in crude oil is complex, and the relative concentrations of specific gases and vapors are highly variable. When a worker opens a tank, the worker's breathing zone can immediately become an acutely toxic mix of concentrated hydrocarbon gases and vapors. Depending on weather conditions, the plume may disperse or engulf workers atop and around tank batteries.

Appendix A shows how hydrocarbon gases and vapors behave when they are released from a production tank. Appendix B lists exposure limits for common hydrocarbon gases and vapors.

\section{Health Hazards of Hydrocarbon Gases and Vapors}

Acute exposures to hydrocarbon gases and vapors can affect the eyes, lungs, and central nervous system. If present in sufficient concentrations to displace oxygen, this exposure can sensitize the heart to stress hormones, such as catecholamines, causing abnormal rhythms and ventricular fibrillation that can lead to sudden death [Adgey et al. 1995; Bass 1970; Martinez et al. 2012; NIOSH 2005a,b,c; Poklis 1976; Reinhardt et al. 1971; Riihimäki and Savolainen 1980]. Even a brief exposure (30 seconds or less) to high concentrations of hydrocarbons and a low-oxygen atmosphere can result in the rapid onset of respiratory depression, hypoxia, and fatal cardiac arrhythmias [Miller and Mazur 1984]. Pre-existing coronary artery disease may exacerbate the risk. These exposures can also have narcotic effects, causing dizziness, rapid disorientation, and confusion that could lead to loss of judgment, narcosis, and incapacitation [Drummond 1993;

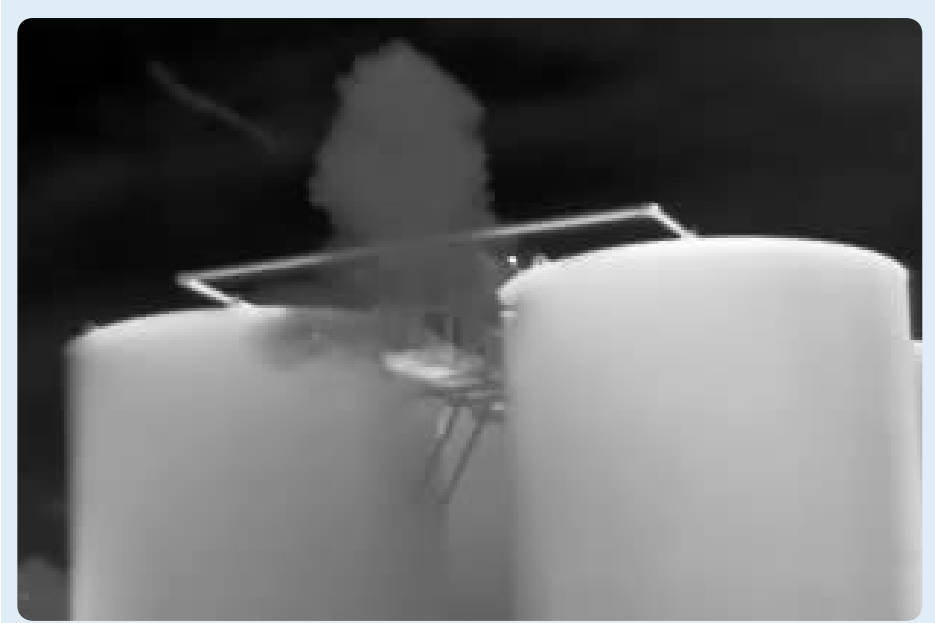

Forward-looking infrared (FLIR) photograph of the initial hydrocarbon plume after a thief hatch on a production tank battery is opened. The plume later expands to many times its initial size. Image: John Snawder, NIOSH.

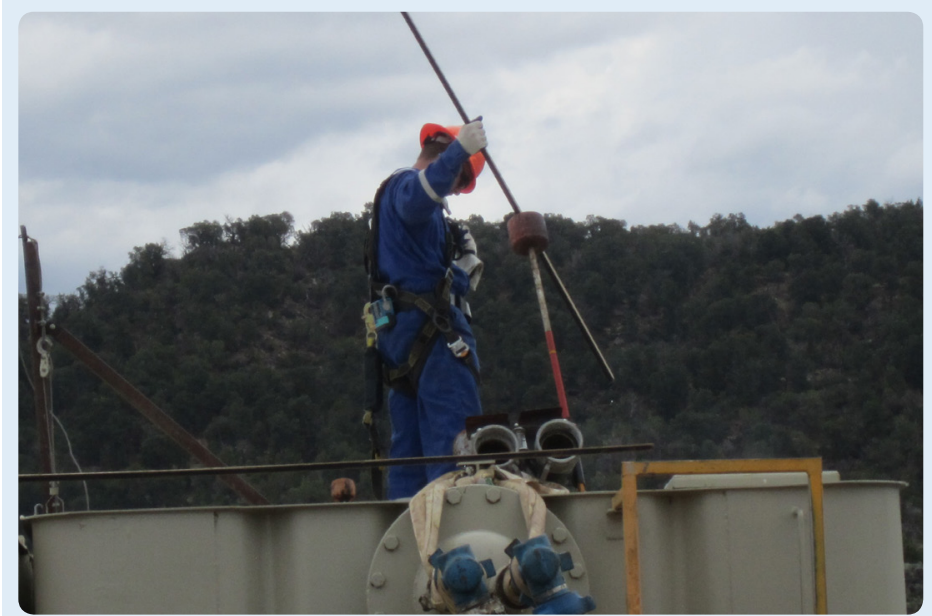

A worker manually gauges a flowback tank. The thief hatch is directly in front of his feet, and the gas and vapor released is invisible. Image: Max Kiefer, NIOSH.

Sugie et al. 2004]. Some hydrocarbons are also known carcinogens (e.g., benzene) [ATSDR 2007]. 


\section{Factors that may increase worker exposure to hydrocarbon gases and vapors and flammable atmospheres}

1. Produced Fluid and Reservoir Characteristics

- Condensate and lighter crude (versus heavy crude)

- Unstabilized (non-degassed) crude oils

- High gas to oil ratio fluids

- High temperature fluids

- High production volumes/early in production

2. Operational and Task-related Factors

- Drilling out plugs during completion operations

- Tanks that are not isolated prior to opening hatch

- Interconnected tanks (tank batteries)

- Tanks using flare systems with backpressure on the vapor space

- Flowback operations

- Working around tanks with vapor recovery units

- Maintenance work

- Working around separators/enclosed spaces

3. Environmental Factors

- Higher temperatures

- Weather inversions

- Higher altitude

- Low wind speed

\section{Factors that may decrease worker exposure to hydrocarbon gases and vapors and flammable atmospheres}

1. Engineering Controls

- Remote or automatic gauging and sampling

- Blowdown valves

- Tank sampling taps

- Thief hatch pressure indicators, etc.

2. Work Practices

- Working upwind and at a distance from open hatches

3. Personal Protective Equipment (PPE)

- Flame retardant clothing

- Appropriate respiratory protection

- Impermeable gloves

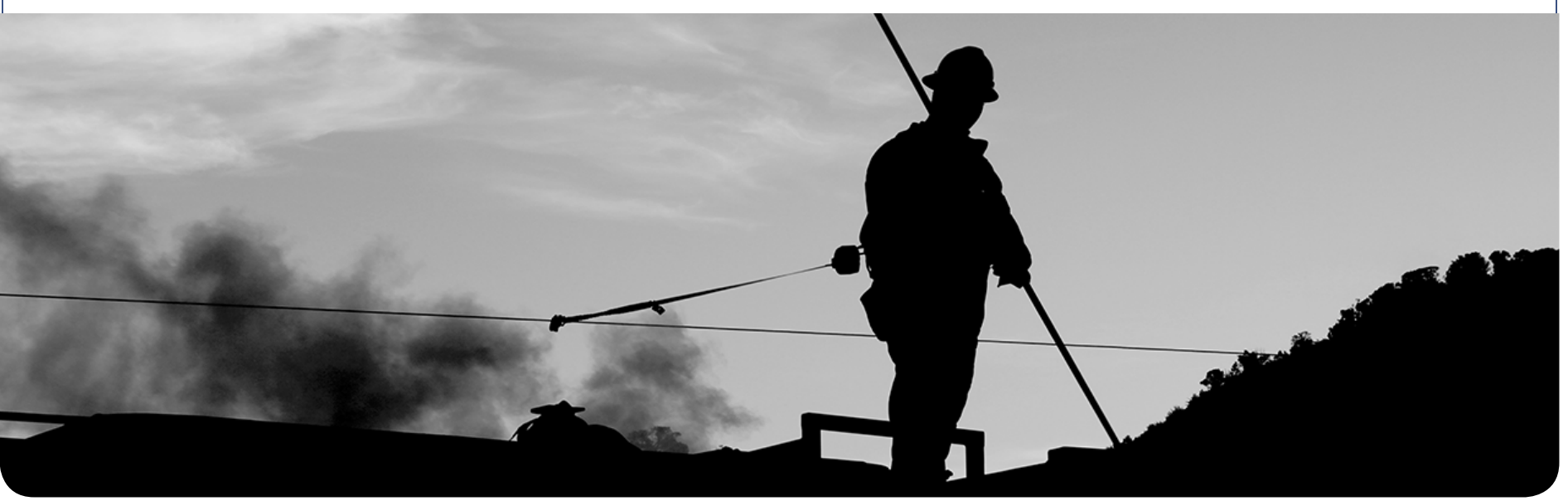




\section{Worker Fatalities during Manual Tank Gauging and Fluid Sample Collection, 2010-2014}

NIOSH researchers, OSHA officials, and academic occupational health researchers investigated reports of worker deaths from 2010 through 2014 associated with manual tank gauging and the collection of fluid samples (Appendix C). During the 5-year period, NIOSH researchers identified nine fatalities involving these tasks. Three deaths occurred in North Dakota, three in Colorado, one in Texas, one in Oklahoma, and one in Montana.

All fatalities occurred at crude oil production tanks. Four took place during tank gauging, and five happened during fluid sample collection at an open thief hatch by pumpers/ truckers. For all fatalities, the employees were working alone or not being observed by a co-worker. Unprotected exposures to high concentrations of hydrocarbon gases and vapors and/or displacement of oxygen are believed to be primary or contributory factors in each fatality [Harrison et al. 2016]. Exposure to $\mathrm{H}_{2} \mathrm{~S}$ was ruled out as a cause in all nine cases. A narrative description of each of the nine fatalities can be found on the NIOSH "Fatalities in the Oil and Gas Extraction Industry" (FOG) database web page (http://www.cdc.gov/niosh/topics/fog/data.html).

Oxygen concentrations well below normal (oxygen concentration in ambient air $=21 \%$ ) were documented in two fatal incidents. While investigating the Case \#1 death at the site, OSHA's compliance officer measured oxygen levels in the range of $11 \%$ to $12 \%$ approximately one foot above the open hatch. A data-logging four-gas monitor worn by the worker at the time of death in Case \#7 recorded that the oxygen level fell to as low as $6.9 \%$. The same worker had also worn the monitor during a previous incident, during which the oxygen level fell to as low as $9.1 \%$, and remained consistently below $15 \%$ for a six-minute interval. Exposure to atmospheres with these low concentrations of oxygen can rapidly overcome workers and bring about unconsciousness without warning. Also, in both incidents, the monitor worn by the worker in Case \#7 documented that the worker's environment exceeded the LEL.

\section{NIOSH Evaluation of Worker Exposures during Flowback and Production Activities}

In 2013, NIOSH evaluated worker exposures to a variety of chemicals during flowback and production activities at six well sites in Colorado and Wyoming [Esswein et al. 2014]. Exposure assessments included full-shift and short-term personal breathing zone (PBZ) and area air sampling.
Direct-reading instruments were also used to characterize peak and short-term exposures to hydrocarbon gases and vapors. This study found that most workers gauging tanks (15 of $17 ; 88.2 \%$ ) had benzene exposures exceeding the $\mathrm{NIOSH}$-recommended exposure limit (REL) of 0.1 parts per million (ppm) as a time-weighted average (TWA) for a full shift. Some exposures also exceeded the NIOSH shortterm exposure limit of $1 \mathrm{ppm}$ as a 15-minute average for benzene. Worker exposures to benzene did not exceed the OSHA permissible exposure limit (PEL) criteria (1 ppm as a TWA) and biological monitoring results did not exceed criteria established by the American Conference of Governmental Industrial Hygienists for benzene [OSHA 2012]. However, average benzene exposures for workers who gauged tanks were approximately five times greater than for workers not gauging tanks. In the same study, direct-reading instruments detected benzene peak concentrations at open hatches exceeding 200 ppm, and sustained atmospheres as high as $40 \%$ of the LEL adjacent to separators and flowback tanks. Concentrations above $10 \%$ of the LEL are considered a risk for fires or explosions and are classified as Immediately Dangerous to Life and Health (IDLH) by OSHA and NIOSH. Workers at the sites did not use respiratory protection while gauging tanks.

\section{OSHA Evaluation of Exposures to Workers during Tank Gauging}

In 2014, OSHA industrial hygienists conducted evaluations at oil and gas extraction well sites in North Dakota. The sites were identified by observing active tank-gauging operations. The evaluations characterized worker exposures during manual tank gauging for full-shift, shortterm, and peak concentrations of hydrocarbon gases and vapors, and flammable and oxygen-deficient environments. Samples collected approximately one foot above open hatches found IDLH concentrations of hydrocarbon gases and vapors, including propane, pentane, methyl butane, hexane, 2-methyl pentane, and 3-methyl pentane (Table 1).

Worker sampling also documented overexposures to benzene for short-term, ceiling, and 8-hour TWA concentrations, based on the OSHA PELs. Potentially flammable (>10\% LEL) and oxygen-deficient atmospheres ( $<19.5 \%$ oxygen) were identified on production tanks when thief hatches were opened during gauging and sampling [Jordan 2015].

Samples documented total hydrocarbon gas and vapor concentrations of $179,000 \mathrm{ppm}$ and $219,000 \mathrm{ppm}$ in the plumes above two thief hatches. Laboratory analyses identified break-through of hydrocarbon gases in the sampling media, indicating that actual concentrations might have been greater than reported. 
Sample collection methods are under development to more accurately assess hydrocarbon gas and vapor concentrations during manual thieving (i.e., sampling) and gauging. Consistent with the NIOSH field research, the OSHA evaluations identified worker exposure risks for hydrocarbon gases and vapors, and fires and explosions.

Table 1. Hydrocarbon Gas and Vapor Concentrations Measured by OSHA

Approximately 1 Foot Above Open Production Tank Hatches (North Dakota, 2014).

\begin{tabular}{|l|c|c|c|}
\hline Gas or Vapor & Concentration (average ppm) & IDLH* (average ppm) & Severity** \\
\hline Propane & 43,000 & 2,100 & $>20 \mathrm{x}$ \\
\hline Butane(s) & 100,000 & 1,900 & $>50 \mathrm{x}$ \\
\hline Pentane(s) & 28,000 & 1,500 & $>20 \mathrm{x}$ \\
\hline $\mathrm{n}$-Hexane & 4,500 & 1,100 & $>4 \mathrm{x}$ \\
\hline Benzene & $100-400$ & 500 & $<1 \mathrm{x}$ \\
\hline
\end{tabular}

*Immediately Dangerous to Life or Health concentrations expressed as $10 \%$ of the LEL

${ }^{* *}$ Severity = Airborne Concentration Expressed as ppm / IDLH (ppm)

\section{Appropriate Respiratory Protection}

Although air-purifying respirators with organic vapor cartridges can protect against vapors (such as benzene, hexane, toluene, and xylene), they are ineffective against light hydrocarbon gases (such as methane, ethane, propane, butane, and pentane) because these gases quickly pass through the activated charcoal sorbent in respirator cartridges [Freedman et al. 1973; 3M 2013]. Air-purifying respirators also have other important limitations. They do not protect against oxygendeficient atmospheres or concentrations of hydrocarbons exceeding the maximum use concentration (Occupational Exposure Limit $X$ the Assigned Protection Factor) for the respirator/cartridge ensemble.

Workers using half-face or full-face air-purifying respirators while tank gauging will not be protected against exposures to light hydrocarbon gases and vapors and oxygen-deficient atmospheres. At least one worker who died was wearing an airpurifying respirator at the time of his death. Supplied air respirators (e.g., air-line or self-contained breathing apparatus [SCBA]) can protect workers from toxic exposures and oxygen-deficient atmospheres - provided the user is wearing the respirator correctly in accordance with the OSHA Respiratory Protection Standard (29 CFR 1910.134) [OSHA 2006].

\section{Conclusions}

Exposure assessment studies conducted by NIOSH and OSHA have identified worker health and safety risks that occur when workers open thief hatches and manually gauge and sample fluids from production and flowback tanks. Toxicological data, inherent factors from the oil collection process, and exposure assessments provide evidence that gauging and sampling tanks present significant hazards to workers, including risks for exposures to oxygen-deficient atmospheres, inhalation exposures to concentrated petroleum hydrocarbon gases and vapors, and fires and explosions.

Moreover, nine fatalities identified over five years were associated with working close to open hatches of crude oil production tanks. Exposures to hydrocarbon gases and vapors and/or oxygen-deficient atmospheres are believed to be primary or contributory factors to these workers' deaths.

Hydrocarbon gas and vapor emissions from production and flowback tanks are wide-ranging. Consequently, it is difficult to predict the magnitude of risk from any specific gauging or sampling task. Factors that can affect the extent of the occupational exposures are presented in Box 1, page 3. These factors should be considered as part of worker exposure assessments.

$\mathrm{NIOSH}$ and OSHA recommend that employers take the following steps to ensure that workers are properly aware of the hazards and protected from exposure to hydrocarbon gases and vapors. 
1. Implement alternative tank gauging and sampling procedures that enable workers to monitor tank fluid levels and take samples without opening the tank hatch.

2. Retrofit existing tanks with dedicated sampling ports (i.e., tank sampling taps [American Petroleum Institute 2013]) that minimize worker exposures to hydrocarbon gases and vapors, thereby eliminating the need to routinely open thief hatches to sample. These sampling taps should minimize the magnitude of hydrocarbon plumes and should limit the need for workers to access the top of tanks.

3. Install thief hatch pressure indicators to provide an immediate visual indicator of tank pressures and potential hazards. Pressure indicators can show workers the pressure in the tank and allow a trained worker to follow appropriate procedures, such as actuating a blowdown valve, venting gas to a flare, or using appropriate respiratory protection, such as a self-contained breathing apparatus or an air-line respirator.

4. Conduct worker exposure assessments to determine exposure risks to volatile hydrocarbons and other contaminants. Employers may consult an occupational safety and health professional trained and certified in industrial hygiene and who has knowledge and experience with combined flammable gas and vapor exposures to ensure that an appropriate air-sampling strategy is used.

5. Provide hazard communication training in a language that employees understand to ensure that general site workers, tank gaugers and samplers, water haulers, drivers, and others who open tank hatches understand the hazards associated with opening tanks and the precautions necessary to conduct this work safely. These hazards include reduced oxygen environments, flammability hazards and possible ignition sources, and the potential for concentrations of hydrocarbons that can approach or exceed IDLH concentrations. Post hazard signage at access stairs, catwalks, and/or tanks to alert workers about the hazards associated with opening thief hatches and precautions that must be taken.
6. Ensure that workers are trained on - and correctly and consistently use - calibrated multi-gas and oxygen monitors that measure percent LEL and oxygen concentration. Workers should understand the limitations of these monitors as well as appropriate actions to take whenever an alarm occurs or they experience health symptoms (e.g., leave the hazard area, report symptoms to supervisors).

7. Do not permit employees to work alone when tank gauging or working around tanks, thief hatches, or other areas where they may encounter process fluids. Observers should be trained on proper rescue procedures and be stationed outside potentially hazardous areas.

8. As an interim measure, where remote gauging or sampling is not feasible or engineering controls are not implemented, (a) train workers in proper work practices, such as tank-opening procedures, that can minimize risks for exposures, (b) ensure intrinsic safety by proper grounding and prohibiting the use of spark producing devices or equipment, (c) establish administrative controls to reduce the number of times throughout a shift a worker is required to manually gauge tanks, (d) safely reduce tank pressure prior to gauging, and (e) use appropriate respiratory protection, including a supplied air respirator (SAR) and/or self-contained breathing apparatus (SCBA) in areas where IDLH VOC exposures may occur (i.e., during manual tank gauging/sampling). Employers should consult with a trained occupational safety and health professional to determine the appropriate respirator to be used. $\mathrm{NIOSH}$ guidance for selecting respirators is at: http:// www.cdc.gov/niosh/docs/2005-100/default.html.

9. Wear flame-resistant clothing to protect against burns from fires and explosions. Also, use appropriate impermeable gloves to limit risks for skin exposures to chemicals (e.g., benzene).

10. Establish and practice emergency procedures to provide on-scene, immediate medical response in the event of an incident, such as a collapsed worker, or workers experiencing symptoms of chemical overexposures or exposure to an oxygen-deficient atmosphere. 


\section{How Can OSHA and NIOSH Help?}

OSHA has compliance assistance specialists throughout the nation who can provide information to employers and workers about OSHA standards, short educational programs on specific hazards or OSHA rights and responsibilities, and information on additional compliance assistance resources. Contact your local OSHA office for more information.

OSHA's On-site Consultation Program offers free and confidential safety and health services to small and mediumsized businesses in all states and territories across the country, with priority given to high-hazard worksites. On-site Consultation services are separate from enforcement and do not result in penalties or citations. Consultants from state agencies or universities work with employers to identify workplace hazards, provide advice on compliance with OSHA standards, and assist in establishing and improving their safety and health management systems. To locate the OSHA On-site Consultation Program nearest you, call 1-800-321-6742 (OSHA) or visit http://www.osha.gov/dcsp/smallbusiness/ index.html.

OSHA's and NIOSH's Cooperative Initiatives: OSHA, NIOSH, and the National STEPS Network have formed an Alliance (http://www.osha.gov/dcsp/alliances/steps_niosh/steps_niosh.html) to develop products that will reduce fatalities and injuries in this industry. Additionally, OSHA, NIOSH, and several U.S. onshore exploration and production industry trade associations, companies, and individual experts have formed an Emerging Issues Focus Group to further explore worker hazards during oil and gas extraction and to develop practical short- and long-term solutions to protect worker safety and health. Look for products and updates from these groups.

NIOSH can help characterize exposures at your workplace and is looking for industry partners to evaluate engineering controls that may reduce exposure to hydrocarbon gases and vapors. NIOSH is also looking for additional partners in drilling and well servicing to help evaluate worker exposures to other chemical hazards and develop controls as needed. Please refer to the document NIOSH Field Effort to Assess Chemical Exposure Risks to Gas and Oil Workers: (http://www. cdc.gov/niosh/docs/2010-130/) for details and contact information if you have questions or wish to participate.

In addition, NIOSH has an active program that encourages Prevention through Design considerations so that occupational health and safety aspects are built into equipment during the design phase.

Employers and workers can always request a NIOSH Health Hazard Evaluation. For more information about this program, please visit the website - (http://www.cdc.gov/niosh/hhe/HHEprogram.html).

\section{Worker Rights}

Workers have the right to:

- Working conditions that do not pose a risk of serious harm.

- Receive information and training (in a language and vocabulary they understand) about workplace hazards, methods to prevent them, and the OSHA standards that apply to their workplace.

- Review records of work-related injuries and illnesses.

- Get copies of test results that find and measure hazards.

- File a complaint asking OSHA to inspect their workplace if they believe there is a serious hazard or that their employer is not following OSHA's rules. OSHA will keep all identities confidential.

- Exercise their rights under the law without retaliation or discrimination.

For more information, see OSHA's page for workers (https://www.osha.gov/workers/index.html). 


\section{Contact OSHA}

For questions or to get information or advice, to report an emergency, fatality, inpatient hospitalization, amputation or loss of an eye, or to file a confidential complaint, contact your nearest OSHA office, visit www.osha.gov, or call OSHA at 1-800-321-OSHA (6742), TTY 1-877-889-5627.

There are 28 OSHA-approved occupational safety and health State Plans. State Plans are required to have standards and enforcement programs that are at least as effective as federal OSHA's and may have different or more stringent standards. More information about State Plans is available at: http://www.osha.gov/dcsp/osp/index.html

\section{Contact NIOSH}

To receive documents or more information about occupational safety and health topics, please contact NIOSH at 1-800-CDC-INFO (1-800-232-4636), TTY 1-888-232-6348, email: cdcinfo@cdc.gov or visit the NIOSH web site at: http:// www.cdc.gov/niosh/.

\section{Suggested Citation:}

NIOSH [2016]. NIOSH/OSHA Hazard Alert. Health and Safety Risks for Workers Involved in Manual Tank Gauging and Sampling at Oil and Gas Extraction Sites. U.S. Department of Health and Human Services, Centers for Disease Control and Prevention, National Institute for Occupational Safety and Health, DHHS (NIOSH) Publication No. 2016-108.

\section{Acknowledgements:}

NIOSH and OSHA acknowledge Robert Harrison, MD, (University of California, San Francisco) for his valuable assistance in identifying worker fatalities related to tank gauging and sampling. NIOSH and OSHA gratefully acknowledge Michael Kosnett, MD, MPH, and Margaret Cook-Shimanek, MD, MPH (University of Colorado, Denver and Colorado School of Public Health) for their expertise and counsel in medical toxicology relating to hydrocarbon exposures and risks for sudden death, and their discussions of a specific fatality investigation.

NIOSH and OSHA also thank and acknowledge Rick Ingram of the National STEPS Network for his enduring leadership at the National STEPS Network and the recently formed OSHA Alliance, along with his support of the NIOSH Field Effort to Assess Chemical Exposures in Oil and Gas Workers.

$\mathrm{NIOSH}$ acknowledges our industry partners (and especially their workers) for their leadership in occupational health and safety, as demonstrated by their participation in the NIOSH Field Effort to Assess Chemical Exposures in Oil and Gas Workers.

\section{Appendix A.}

\section{Behavior of Hydrocarbon Gases and Vapors in a Production Tank}

1. Hydrocarbon gases and vapors exist in equilibrium with liquid hydrocarbons (e.g., crude oil) in a production tank.
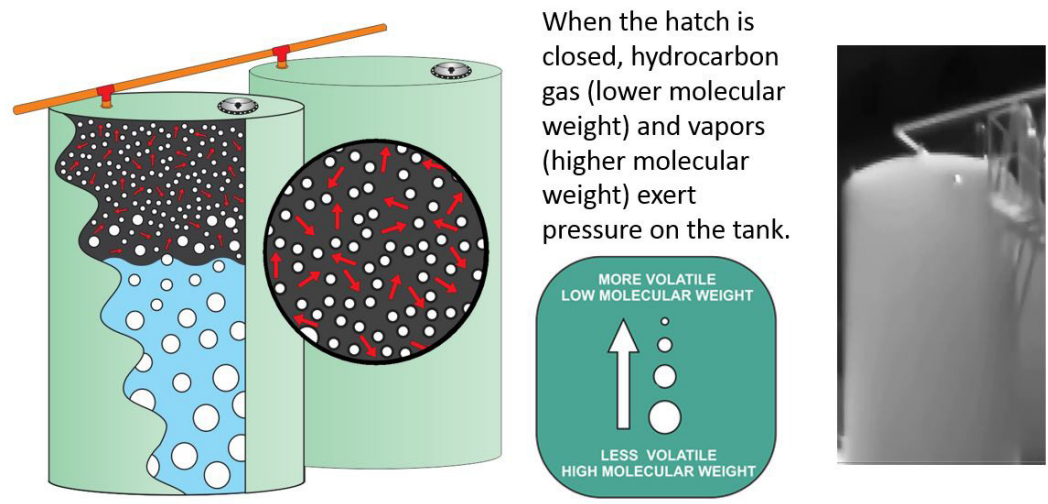
2. Gases (previously in equilibrium with crude oil in a pressurized tank) release to the atmosphere when the tank lid is opened.

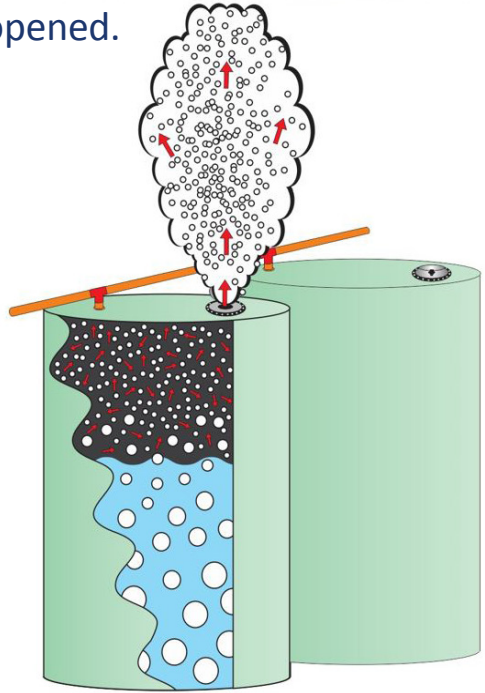

When the hatch is opened, a large volume of gases (mostly propane and butane) rush out. These gases can displace oxygen in the immediate work area, and this could asphyxiate workers in the vicinity.

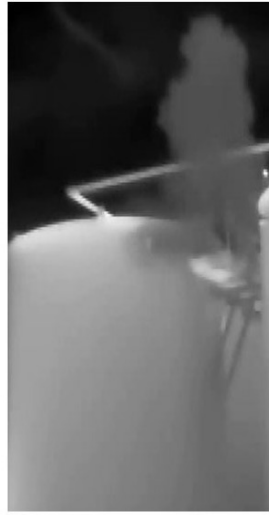

3. Vapors form when liquid hydrocarbons inside the tank evaporate.

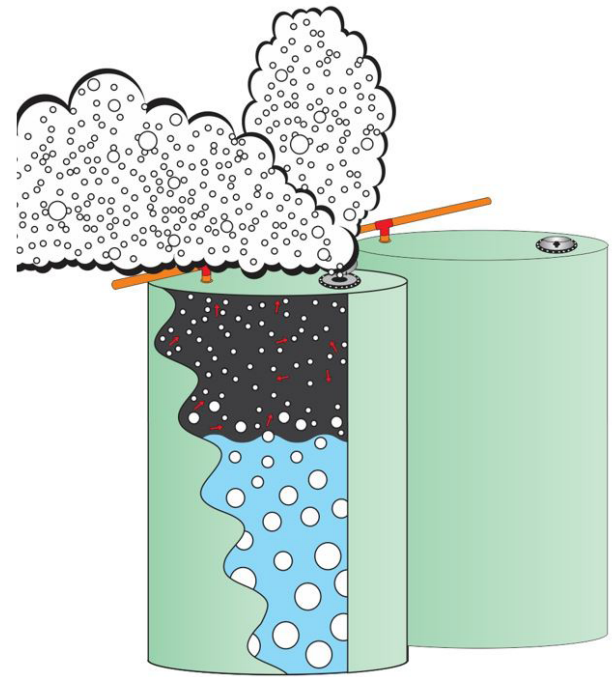

As the hatch remains open, heavier hydrocarbon molecules (pentane, hexane, heptane) also begin to leave the tank and enter the workspace. The rate of release is high, and these gases and vapors may reach concentrations that can be toxic or flammable.

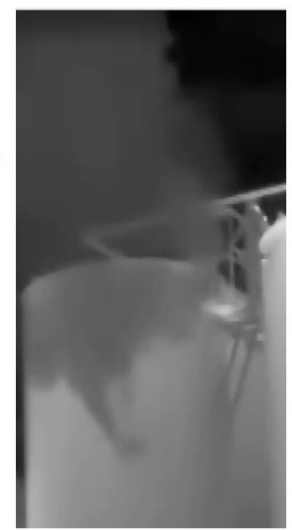

4. Hydrocarbon gases and vapors are generated at a slower pace as tank pressure decreases. Lighter hydrocarbon gases and vapors stay aloft; denser gases and vapors seek the ground.

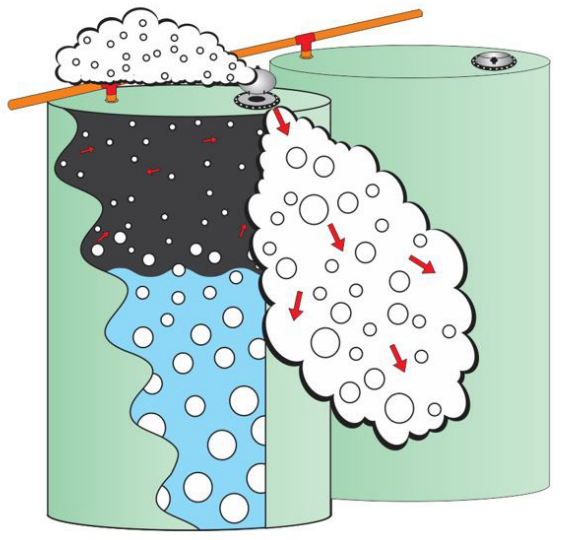

As the hatch continues to remain open, the gases and vapors in the tank are approaching equilibrium with the environment, significantly slowing the rate of emission.

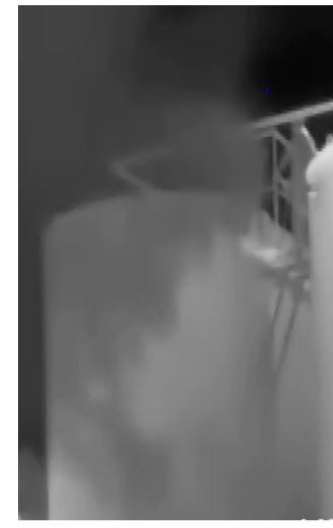

Graphics: Cindy Striley, NIOSH. Photographs: John Snawder, NIOSH. 


\section{Appendix B.}

\begin{tabular}{|c|c|c|c|c|c|}
\hline \multicolumn{6}{|c|}{$\begin{array}{l}\text { Examples of Volatile Hydrocarbons Commonly Present in Oil and Gas Process Fluids, } \\
\text { NIOSH Recommended Exposure Limits (RELs), OSHA Permissible Exposure Limits (PELs), } \\
\text { Lower and Upper Explosive Limits (LEL and UEL). }\end{array}$} \\
\hline Compound & REL & PEL & IDLH & LEL & UEL \\
\hline Methane & \multicolumn{2}{|c|}{ None (asphyxiant) } & $\begin{array}{c}5,000 \text { ppm } \\
\text { (10\% LEL) }\end{array}$ & $\begin{array}{c}5.00 \% \\
50,000 \text { ppm }\end{array}$ & $\begin{array}{c}15.00 \%{ }^{* *} \\
150,000 \mathrm{ppm}\end{array}$ \\
\hline Ethane & \multicolumn{2}{|c|}{ None (asphyxiant) } & $\begin{array}{c}3,000 \mathrm{ppm} \\
\text { (10\% LEL) }\end{array}$ & $\begin{array}{c}3.00 \% \\
30,000 \mathrm{ppm}\end{array}$ & $\begin{array}{c}12.50 \%{ }^{* *} \\
125,000 \mathrm{ppm}\end{array}$ \\
\hline Propane & $1,000 \mathrm{ppm}$ & 1,000 ppm & $\begin{array}{c}2,100 \mathrm{ppm} \\
(10 \% \mathrm{LEL})\end{array}$ & $\begin{array}{c}2.10 \% \\
21,000 \text { ppm }\end{array}$ & $\begin{array}{c}9.50 \%{ }^{* * *} \\
95,000 \mathrm{ppm}\end{array}$ \\
\hline n-Butane & 800 ppm & none & $\begin{array}{c}1,600 \mathrm{ppm} \\
\text { (10\% LEL) }\end{array}$ & $\begin{array}{c}1.60 \% \\
16,000 \mathrm{ppm} \\
\end{array}$ & $\begin{array}{c}8.40 \%{ }^{* * *} \\
84,000 \mathrm{ppm} \\
\end{array}$ \\
\hline i-Butane & 800 ppm & none & $\begin{array}{c}1,600 \text { ppm } \\
\text { (10\% LEL) }\end{array}$ & $\begin{array}{c}1.60 \% \\
16,000 \text { ppm }\end{array}$ & $\begin{array}{c}8.40 \%{ }^{* * *} \\
84,000 \mathrm{ppm} \\
\end{array}$ \\
\hline n-Pentane & $\begin{array}{l}1120 \text { ppm } \\
\text { (610 ppm 15-minute } \\
\text { ceiling limit) }\end{array}$ & 1,000 ppm & $\begin{array}{c}\text { 1,500 ppm } \\
\text { (10\% LEL) }\end{array}$ & $\begin{array}{c}1.50 \% \\
15,000 \mathrm{ppm}\end{array}$ & $\begin{array}{c}7.80 \%{ }^{* * *} \\
78,000 \mathrm{ppm}\end{array}$ \\
\hline n-Hexane & 50 ppm & $500 \mathrm{ppm}$ & $\begin{array}{c}1,100 \mathrm{ppm} \\
(10 \% \mathrm{LEL})\end{array}$ & $\begin{array}{c}1.10 \% \\
11,000 \mathrm{ppm}\end{array}$ & $\begin{array}{c}7.50 \%{ }^{* * *} \\
75,000 \mathrm{ppm}\end{array}$ \\
\hline Benzene $^{* * * *}$ & $\begin{array}{c}0.1 \mathrm{ppm} \\
\text { (1 ppm STEL) }\end{array}$ & $1 \mathrm{ppm}$ & 500 ppm & $\begin{array}{c}1.20 \% \\
12,000 \mathrm{ppm} \\
\end{array}$ & $\begin{array}{c}7.80 \%{ }^{* * *} \\
78,000 \mathrm{ppm} \\
\end{array}$ \\
\hline Heptane & $\begin{array}{c}85 \mathrm{ppm} \\
\text { (440 ppm } \\
\text { 15-minute ceiling } \\
\text { limit) }\end{array}$ & 500 ppm & 750 ppm & $\begin{array}{c}1.00 \% \\
10,500 \mathrm{ppm}\end{array}$ & $\begin{array}{c}6.70 \%^{* * *} \\
67,000 \text { ppm }\end{array}$ \\
\hline Ethyl Benzene & $\begin{array}{c}100 \text { ppm } \\
\text { (125 ppm STEL) }\end{array}$ & 100 ppm & $\begin{array}{l}800 \mathrm{ppm} \\
(10 \% \mathrm{LEL})\end{array}$ & $\begin{array}{c}0.80 \% \\
8,000 \mathrm{ppm} \\
\end{array}$ & $\begin{array}{c}6.70 \%{ }^{* * *} \\
67,000 \mathrm{ppm} \\
\end{array}$ \\
\hline Toluene & $\begin{array}{c}100 \text { ppm } \\
\text { (150 ppm STEL) }\end{array}$ & $200 \mathrm{ppm}$ & $500 \mathrm{ppm}$ & $\begin{array}{c}1.10 \% \\
11,000 \text { ppm }\end{array}$ & $\begin{array}{c}7.10 \%{ }^{* * *} \\
71,000 \mathrm{ppm}\end{array}$ \\
\hline Xylenes & $\begin{array}{c}100 \text { ppm } \\
\text { (150 ppm STEL) }\end{array}$ & $100 \mathrm{ppm}$ & 900 ppm & $\begin{array}{c}0.90 \% \\
9,000 \mathrm{ppm} \\
\end{array}$ & $\begin{array}{c}7.00 \%^{* *} \\
70,000 \mathrm{ppm} \\
\end{array}$ \\
\hline $\begin{array}{l}\text { Mixed Petroleum } \\
\text { Hydrocarbons/ } \\
\text { Distillates } \\
\text { (naphthas) }\end{array}$ & $\begin{array}{l}350 \mathrm{mg} / \mathrm{m}^{3}(1800 \\
\mathrm{mg} / \mathrm{m}^{3} 15-\text { minute } \\
\text { ceiling limit) }\end{array}$ & $500 \mathrm{ppm}$ & 1100 ppm & $\begin{array}{c}1.10 \% \\
11,000 \text { ppm }\end{array}$ & $\begin{array}{c}5.90 \%{ }^{* *} \\
59,000 \text { ppm }\end{array}$ \\
\hline
\end{tabular}

* When the health-based immediately dangerous to life or health (IDLH) values are greater than $10 \%$ of the lower explosive limit (LEL) of the air contaminant, the IDLH value is set at $10 \% \mathrm{LEL}$, because explosive hazards are deemed a greater risk than toxicity$\mathrm{NIOSH}$, Current Intelligence Bulletin 66 (http://www.cdc.gov/niosh/docs/2014-100/). An IDLH is a maximum airborne concentration above which only a highly reliable breathing apparatus providing maximum worker protection is permitted [NIOSH 2004]. IDLH values are based on a 30-minute exposure duration. Upper explosive limit (UEL) is the highest concentration (\%) of a gas or a vapor in air capable of producing a flash or fire in the presence of an ignition source. Concentrations higher than the UEL are "too rich" to burn.

** International Chemical Safety cards: http://www.cdc.gov/niosh/ipcs/

***NIOSH Pocket Guide to Chemical Hazards: http://www.cdc.gov/niosh/npg/npgd0524.html

**** Upstream oil and gas operations are exempt from the OSHA Benzene standard, 1910.1028. 


\section{Appendix C.}

\section{Worker Fatalities Related to Oxygen Deficiency and Inhalation of Hydrocarbon Gases and Vapors Among Oil and Gas Extraction Workers-Multiple States, 2010 to 2014}

\begin{tabular}{|c|c|c|c|c|c|c|c|c|}
\hline & $\begin{array}{l}\text { Year of } \\
\text { death }\end{array}$ & $\begin{array}{l}\text { Age, in } \\
\text { years }\end{array}$ & State & Job Title & Job Task & $\begin{array}{l}\text { Description of how } \\
\text { person was found }\end{array}$ & $\begin{array}{l}\text { Time of day } \\
\text { found }\end{array}$ & Coroner's stated cause of death \\
\hline 1 & 2010 & 30 & MT & $\begin{array}{l}\text { Crew } \\
\text { Worker }\end{array}$ & Gauging & $\begin{array}{l}\text { Slumped over on the } \\
\text { catwalk }\end{array}$ & 3:00 a.m. & $\begin{array}{l}\text { Hypertensive and atherosclerotic } \\
\text { cardiovascular disease }\end{array}$ \\
\hline 2 & 2012 & 21 & ND & $\begin{array}{l}\text { Flow } \\
\text { Tester }\end{array}$ & Gauging & $\begin{array}{l}\text { On catwalk next to } \\
\text { open hatch }\end{array}$ & 12:30 a.m. & $\begin{array}{l}\text { Hydrocarbon poisoning due to inhalation of } \\
\text { petroleum vapors }\end{array}$ \\
\hline 3 & 2013 & 39 & ND & $\begin{array}{l}\text { Truck } \\
\text { Driver }\end{array}$ & $\begin{array}{l}\text { Collecting } \\
\text { Sample }\end{array}$ & $\begin{array}{l}\text { Slumped over catwalk } \\
\text { railing on knees in } \\
\text { front of open hatch }\end{array}$ & 10:20 a.m. & $\begin{array}{l}\text { Sudden cardiac arrhythmia (primary), morbid } \\
\text { obesity and arteriosclerotic heart disease } \\
\text { (contributory) }\end{array}$ \\
\hline 4 & 2014 & 57 & OK & $\begin{array}{l}\text { Truck } \\
\text { Driver }\end{array}$ & $\begin{array}{l}\text { Collecting } \\
\text { Sample }\end{array}$ & $\begin{array}{l}\text { On catwalk next to } \\
\text { tank, slumped over }\end{array}$ & $\begin{array}{l}\text { 10:12 a.m. } \\
\text { (time of } \\
\text { death) }\end{array}$ & Undetermined (no autopsy performed) \\
\hline 5 & 2014 & 51 & $\mathrm{CO}$ & $\begin{array}{l}\text { Truck } \\
\text { Driver }\end{array}$ & $\begin{array}{l}\text { Collecting } \\
\text { Sample }\end{array}$ & $\begin{array}{l}\text { Hanging from } \\
\text { guardrail, hooked by } \\
\text { clothing }\end{array}$ & $\begin{array}{l}\text { 10:39 a.m. } \\
\text { (time of } \\
\text { death) }\end{array}$ & $\begin{array}{l}\text { Sudden cardiac death due to ischemic heart } \\
\text { disease }\end{array}$ \\
\hline 6 & 2014 & 57 & $\mathrm{CO}$ & $\begin{array}{l}\text { Truck } \\
\text { Driver }\end{array}$ & $\begin{array}{l}\text { Collecting } \\
\text { Sample }\end{array}$ & $\begin{array}{l}\text { Collapsed over open } \\
\text { hatch }\end{array}$ & 10:30 a.m. & Atherosclerotic cardiovascular disease \\
\hline 7 & 2014 & 59 & $\mathrm{CO}$ & $\begin{array}{l}\text { Truck } \\
\text { Driver }\end{array}$ & $\begin{array}{l}\text { Collecting } \\
\text { Sample }\end{array}$ & $\begin{array}{l}\text { Collapsed over open } \\
\text { hatch }\end{array}$ & 1:40 p.m. & $\begin{array}{l}\text { Toxic gas inhalation and oxygen displacement } \\
\text { by volatile hydrocarbons (primary), } \\
\text { atherosclerotic cardiovascular disease and } \\
\text { sudden cardiac death (contributory) }\end{array}$ \\
\hline 8 & 2014 & 63 & $\mathrm{TX}$ & $\begin{array}{l}\text { Tank } \\
\text { Gauger }\end{array}$ & Gauging & $\begin{array}{l}\text { At the bottom of } \\
\text { catwalk stairs }\end{array}$ & 4:14 a.m. & $\begin{array}{l}\text { Arteriosclerotic and hypertensive } \\
\text { cardiovascular disease }\end{array}$ \\
\hline 9 & 2014 & 20 & ND & $\begin{array}{l}\text { Flow } \\
\text { Tester }\end{array}$ & Gauging & $\begin{array}{l}\text { Face down, over open } \\
\text { hatch }\end{array}$ & 5:00 a.m. & $\begin{array}{l}\text { Cardiac arrhythmia, with cardiac } \\
\text { hypertrophy, coronary artery hypogenesis, } \\
\text { obesity and petroleum hydrocarbon vapors }\end{array}$ \\
\hline
\end{tabular}




\section{References}

Adgey AA, Johnston PW, McMechan S [1995]. Sudden cardiac death and substance abuse. Resuscitation, 29(3):219-221.

American Petroleum Institute [2013]. (ASTM D4057). Manual of Petroleum Measurement Standards, Chapter 8.1.

Standard Practice for Manual Sampling of Petroleum and Petroleum Products, Section 8.3.4. Tap Sampling.

ATSDR [2007]. Toxicological Profile for Benzene. Atlanta, GA: U.S. Department of Health and Human Services, Centers for Disease Control and Prevention, Agency for Toxic Substances and Disease Registry DHHS (ATSDR), http://www.atsdr.cdc.gov/ToxProfiles/tp3.pdf.

Bass M [1970]. Sudden sniffing death. JAMA, 212(12) 2,075-2,079.

Drummond I [1993]. Light hydrocarbon gases: a narcotic, asphyxiant, or flammable hazard? App Occup Environ Hyg, 8(2):120-125, http://doi.org/10.1080/1047322X.1993.10388128.

Esswein EJ, Snawder J, King B, Breitenstein M, Alexander-Scott M, Kiefer M [2014]. Evaluation of some potential chemical exposure risks during flowback operations in unconventional oil and gas extraction: preliminary results. J Occup Environ Hyg, 11(10):D174-D184.

Freedman RW, Ferber BI, Hartstein AM [1973]. Service Lives of Respirator Cartridges versus Several Classes of Organic Vapors, Am Ind Hyg Assoc J, 34(2):55-60.

Harrison RJ, Retzer K, Kosnett MJ, et al. Sudden Deaths Among Oil and Gas Extraction Workers Resulting from Oxygen Deficiency and Inhalation of Hydrocarbon Gases and Vapors - United States, January 2010-March 2015. MMWR Morb Mortal Wkly Rep 2016;65:6-9. DOI: http://dx.doi.org/10.15585/mmwr.mm6501a2.

Jordan T [2015]. Hydrocarbon exposures during tank gauging and sampling operations. NORA Oil and Gas Sector Council Meeting, Denver, CO:

http://www.nationalstepsnetwork.com/docs_tank_gauging/NORA_Oil_and_Gas_Council_Meeting_March2015.pdf.

Martinez MA, Ballesteros S, Alcaraz R [2012]. Reporting a sudden death due to accidental gasoline inhalation. Forensic Sci Int, 215(1-3):113-120.

Miller TM, Mazur P [1984].Oxygen deficiency hazards associated with liquefied gas systems: derivation of a program of controls, Am Ind Hyg Assoc J, 45(5):293-298.

NIOSH [2005a]. NIOSH pocket guide to chemical hazards. Benzene. Cincinnati, OH: U.S. Department of Health and Human Services, Centers for Disease Control and Prevention, National Institute for Occupational Safety and Health DHHS (NIOSH) Publication No. 2005-149, http://www.cdc.gov/niosh/npg/npgd0049.html.

NIOSH [2005b]. NIOSH pocket guide to chemical hazards. N-Pentane. Cincinnati, OH: U.S. Department of Health and Human Services, Centers for Disease Control and Prevention, National Institute for Occupational Safety and Health (NIOSH) Publication No. 2005-149, http://www.cdc.gov/niosh/npg/npgd0486.html.

NIOSH [2005c]. NIOSH pocket guide to chemical hazards. Petroleum distillates. Cincinnati, OH: U.S. Department of Health and Human Services, Centers for Disease Control and Prevention, National Institute for Occupational Safety and Health DHHS (NIOSH) Publication No. 2005-149, http://www.cdc.gov/niosh/npg/npgd0492.html.

NIOSH [2015]. Suspected inhalation fatalities involving workers during manual tank gauging, sampling, and fluid transfer operations on oil and gas well sites, 2010-2014. Cincinnati, OH: U.S. Department of Health and Human Services, Centers for Disease Control and Prevention, National Institute for Occupational Safety and Health, http://www.cdc.gov/niosh/topics/fog/data.html. 
National STEPS Network [2015]. Tank Hazard Alert. Washington, DC: OSHA National Alliance.

http://www.nationalstepsnetwork.com/docs_tank_gauging/TankHazardlnfographicFinal04_22_15.pdf

OSHA [no date]. OSHA oil and gas well drilling and servicing eTool, general safety and health, hydrogen sulfide gas, https://www.osha.gov/SLTC/etools/oilandgas/general_safety/h2s_monitoring.html.

OSHA [2006]. Occupational safety and health standards, personal protective equipment. Code of Federal Regulations Title 29, Part 1910.134, https://www.osha.gov/pls/oshaweb/owadisp.show_document?p_table=STANDARDS\&p_id=12716.

OSHA [2012]. Appendix B. Biological exposure guidelines (ACGIH BEl and OSHA expanded standards only), https://www.osha.gov/dts/osta/otm/otm_ii/pdfs/otmii_chpt2_appb.pdf.

Poklis A [1976]. Death resulting from gasoline "sniffing": a case report. J Forensic Sci Soc, 16(1):43-46.

Reinhardt CF, Azar A, Maxfield ME [1971]. Cardiac arrhythmias and aerosol "sniffing." Arch Environ Health, 22(2): 265-279.

Riihimäki V, Savolainen K [1980]. Human exposure to m-xylene. Kinetics and acute effects on the central nervous system. Ann Occup Hyg, 213(4):411-422.

Sugie H, Sasaki C, Hashimoto C, Takeshita H, Nagai T, Nakamura S, Furukawa M, Nishikawa T, Kurihara K [2004]. Three cases of sudden death due to butane or propane gas inhalation: analysis of tissues for gas components. Forensic Sci Int 143(2-3):211-214.

3M [2015]. 3MRespirator Selection Guide. St. Paul, MN: US. 3M Personal Safety Division.

\section{Disclaimer}

This Hazard Alert is not a standard or regulation, and it creates no new legal obligations. It contains recommendations as well as descriptions of mandatory safety and health standards [and other regulatory requirements]. The recommendations are advisory in nature, informational in content, and are intended to assist employers in providing a safe and healthful workplace. The Occupational Safety and Health Act requires employers to comply with safety and health standards and regulations promulgated by OSHA or by a state with an OSHAapproved State Plan. In addition, the Act's General Duty Clause, Section 5(a)(1), requires employers to provide their employees with a workplace free from recognized hazards likely to cause death or serious physical harm. The mention of any non-governmental organization or link to its website in this Hazard Alert does not constitute an endorsement by OSHA or NIOSH of that organization or its products, services, or website.

*Accessibility Assistance: Contact OSHA's Directorate of Technical Support and Emergency Management at (202) 693-2300 for assistance accessing PDF materials All other documents, that are not PDF materials or formatted for the web, are available as Microsoft Office $®$ formats and videos and are noted accordingly. If additional assistance is needed with reading, reviewing or accessing these documents or any figures and illustrations, please also contact OSHA's Directorate of Technical Support and Emergency Management at (202) 693-2300.

${ }^{* *}$ BBooks - EPUB is the most common format for e-Books. If you use a Sony Reader, a Nook, or an iPad you can download the EPUB file format. If you use a Kindle, you can download the MOBI file format.

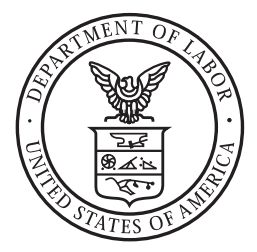

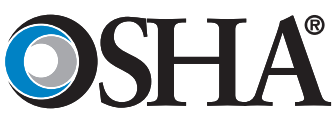

Occupational Safety and Health Administration
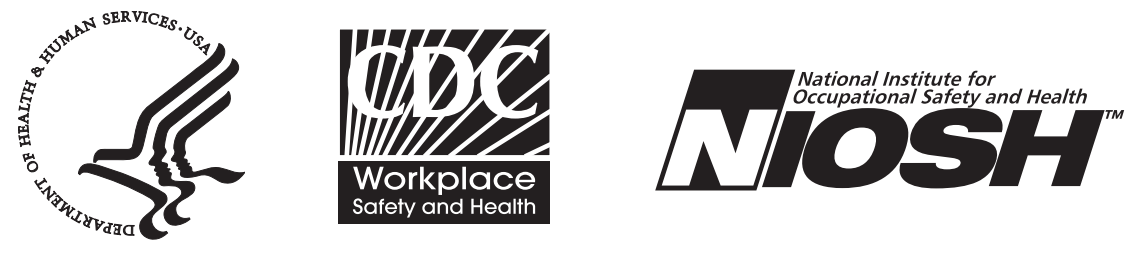